\title{
THE THREE-JUDGE FEDERAL COURT IN CONSTITUTIONAL LITIGATION: A PROCEDURAL ANACHRONISM
}

A federal district court may not grant an injunction restraining the enforcement of a state or federal statute on the ground of unconstitutionality unless the application for the injunction has been heard and determined by three judges. ${ }^{1}$ From the decree of the three-judge district court an appeal lies directly to the Supreme Court. ${ }^{2}$ This extraordinary procedure was originally designed to protect certain state and federal legislative programs from hasty invalidation. However, the procedure has imposed a considerable burden on the courts, and has been a constant source of difficulty for litigants.

The Supreme Court was recently faced with some of these problems in

128 U.S.C. $\$ \S 2281-82$ (1958). Section 2281, which covers injunctions directed against state laws, provides:

"An interlocutory or permanent injunction restraining the enforcement, operation or execution of any State statute by restraining the action of any officer of such State in the enforcement or execution of such statute or of an order made by an administrative board or commission acting under State statutes, shall not be granted by any district court or judge thereof upon the ground of the unconstitutionality of such statute unless the application therefor is heard and determined by a district court of three judges under section 2284 of this title."

Section 2281 is based on 36 Stat. 557 (1910), as amended, 37 Stat. 1013 (1913); 43 Stat. 938 (1925); 56 Stat. 199 (1942); 63 Stat. 968 (1948). For an account of each amendment see notes 15 \& 26 infra. See generally Hart \& WeChSLER, The Federat Courts aNd THe FedERAL SySTEMI 848-55 (1953); ROBERTSON \& KirkHAMr, JuRISDICTION OF THE SUPREJeE CoURT of THE UNited States 344-67 (Wolfson \& Kurland ed. 1951); Bereuffy, The Three Judge Federal Court, 15 Rocky Mi. L. Rev. 64 (1942); Hutcheson, A Case for Three Judges, 47 HaRv, L. Rev. 795 (1934); Bowen, When Are Three Federal Judges Required?, 16 MnN. L. Rev. 1 (1931); Reference, The Three Judge Federal Court, 1 RACE REL. L. REP. 811 (1956).

Section 2282 represents the extension of the three-judge procedure in 1937 to suits for "an interlocutory or permanent injunction restraining the enforcement, operation, or execution of any Act of Congress for repugnance to the Constitution of the United States ...." 50 Stat. 752 (1937), as amended, 62 Stat. 968 (1948). This section differs from section 2281 in that it does not cover injunctions against orders made by administrative boards or commissions. See Jameson \& Co. v. AIorgenthau, 307 U.S. 171 (1939). See generally RoBERTson \& KIRKHAMI, op. cit. supra at 368-375; Frankfurter and Fisher, The Business of the Supreme Courl at October Terms 1935 and 1936, 51 HaRv. L. REv. 577, 610-619 (1937); Note, 51 HaRv. L. Rev. 148 (1937); Note, 48 YALE I. J. 125 (1938).

28 U.S.C. $\$ 2284$ (1958) governs the composition and procedure of the three-judge court. It provides, inter alia:

"In any action or proceeding required ... to be heard and determined by a district court of three judges ... (1) The district judge to whom the application for injunction ... . is presented ... shall notify the Chief Judge of the Circuit, who shall designate two other judges, at least one of whom shall be a circuit judge. ..."

This section is further discussed in note 26 infra.

There are a few other types of cases which require a three-judge court from which an appeal lies to the Supreme Court. The most important of these are suits for an injunction restraining the enforcement of an order of the Interstate Commerce Commission, 28 U.S.C. $\$ 2325$ (1958), and certain antitrust cases which are certified by the attorney general, 63 Stat. 107 (1949), 15 U.S.C. $\$ 28$ (1958), amending 32 Stat. 823 (1903). See generally RobeRTSON \& KIRKHAM, op. cit. supra at $302-12$. These acts will not be discussed in this comment.

228 U.S.C. $\$ 1253$ (1958): "[A]ny party may appeal to the Supreme Court from an order granting or denying, after notice and hearing, an interlocutory or permanent injunction in any civil action ... required ... to be heard and determined by a district court of three judges." Direct appeal has always been provided from three-judge decrees. 
Florida Lime and Avocado Growers v. Jacobsen. ${ }^{3}$ A suit had been brought by a group of Florida avocado growers to enjoin the enforcement of a California statute which prohibits the importation into California of avocados containing less than a certain percentage of oil. The growers attacked the statute on two grounds: first, that it violates the commerce and equal protection clauses of the Constitution, and second, that it is in conflict with the Federal Agricultural Marketing Agreement Act of 1937. The latter contention does not involve a constitutional question. Under the terms of the Three-Judge Act, therefore, three judges would be needed in order to grant an injunction on the first ground, while one judge alone could grant relief on the second ground. A threejudge court was convened to hear the entire case, and the court dismissed the complaint. 4

On direct appeal the Supreme Court addressed itself primarily to the propriety of the convening of the three-judge court. A majority of the Court held that the convening had been proper. The majority rexasoned that the ThreeJudge Act shows a congressional intent that the special court should be formed to decide all claims advanced in attacking a statute so long as at least one such claim asserts the unconstitutionality of the statute. In short, the court must be convened whenever an injunction may be granted on the ground of unconstitutionality. To hold otherwise, the Court stated, "would be to permit one federal district judge to enjoin enforcement of a state statute on the ground of unconstitutionality whenever a non-constitutional ground of attack was also alleged, and this might well defeat the purpose" of the Three-Judge Act. ${ }^{5}$

Mr. Justice Frankfurter dissented, contending that the three-judge court should be formed only when a claim of unconstitutionality is the sole ground of attack on a statute. In all other cases he would permit the single judge to grant relief on either a constitutional or a non-constitutional ground. Justice Frankfurter recognized that to allow the single judge to grant an injunction on a constitutional ground is contrary to the language of the Three-Judge Act. However, he saw the real problem as being a "choice between holding this three judge procedure applicable to a large class of non-constitutional cases, where the unusual demands which that procedure makes upon the federal judiciary were never thought to be justifiable by Congress, and departing from the strictly literal

3362 U.S. 73 (1960).

${ }^{4} 169$ F. Supp. 774 (1958).

5362 U.S. at 80 . The Supreme Court has in several previous cases upheld the convening of a three-judge court where constitutional and non-constitutional claims were joined, but the problem has never been treated at such length as in the instant case. See Railroad Comm'n. v. Pacific Gas \& Elec. Co., 302 U.S. 388, 391 (1938); Oklahoma Gas \& Elec. Co. v. Oklahoma Packing Co., 292 U.S. 386, 390 (1934); Sterling v. Constantin, 287 U.S. 378, 393-94 (1932); Louisville \& N.R.R. v. Garrett, 231 U.S. 298, 303-04 (1913). See also Kurland, The Romero Case and Some Problems of Federal Jurisdiction, 73 HARv. L. Rev. 817, 838-45 (1960). Where an injunction has once been granted on the non-constitutional ground, however, the Supreme Court has held the three-judge procedure and the direct appeal provision inapplicable. $E x$ parte Hobbs, 280 U.S. 168 (1929). 
sense of [the act] in order to restrict the scope of this three judge procedure with a view to preventing its operation outside of its proper, constitutional, sphere."

It may be asked whether the three-judge procedure is ever justified. The problem of the Avocado case is only one of a great many which surround the three-judge system. Others occur more frequently and with far more serious impositions on the courts and on litigants. These problems will be discussed subsequently in this comment. It is proposed first to examine the causes which gave rise to the three-judge procedure and then to inquire whether retention of that procedure is justified today.

I

Both of the Three-Judge Acts in question-that applying to state laws and that applying to acts of Congress-were passed in response to specific problems. The act requiring three judges in order to enjoin the enforcement of an unconstitutional state law $^{7}$ resulted from a controversy in 1908 over the power of the states to regulate transportation and industry. The controversy was set off by the Supreme Court's holding, in Ex parte Young, ${ }^{8}$ that a state's immunity from suit under the eleventh amendment does not extend to suits brought against state officers to restrain them from enforcing unconstitutional laws. ${ }^{9}$ Ex parte Young encouraged railroads and utilities to attack rate-fixing and tax laws, and the result was a deluge of injunctions issued by federal judges suspending such legislation..$^{10}$ The states were bitterly resentful at having their regulatory policies

6 362 U.S. at 91 . Compare Justice Frankfurter's earlier characterization of the Three-Judge Act "not as a measure of broad social policy to be construed with great liberality, but as an enactment technical in the strict sense of the term and to be applied as such." Phillips v. United States, 312 U.S. 246, 251 (1941). See note 66 infra.

${ }^{7}$ See note 1 supra.

8209 U.S. 123 (1908).

9 "Ex parle Young vigorously applied to cases in which rights were asserted under the Fourteenth Amendment the doctrine of Osborn v. Bank [22 U.S. (9 Wheat.) 738 (1824)]: suits to restrain wrongful acts of state officers acting under, or under color of authority from the state are not suits against the state, and where the plaintiffs assert rights protected by the Federal Constitution and laws the federal courts have jurisdiction to entertain them." Hutcheson, supra note 1, at 799.

Ex parte Young was an original application for habeas corpus brought for the release of the Attorney General of Minnesota, who had been committed for contempt when he had attempted to enforce a state statute which a federal district judge had declared to be unconstitutional. The writ was denied. The state statute in question was an act fixing the maximum rates chargeable by railroads in intrastate travel in Minnesota. See also Raymond v. Chicago Union Traction Co., 207 U.S. 20 (1907).

${ }^{10}$ See, e.g., Prentis v. Atlantic Coast Line Co., 211 U.S. 210 (1908) (Virginia order fixing railway passenger rates); Knoxville v. Knoxville Water Co., 212 U.S. 1 (1909) (Tennessee act fixing water rates); R.R. Comm'n. of Louisiana v. Cumberland Tel. \& Tel. Co., 212 U.S. 414 (1909) (Louisiana act fixing telephone rates); Western Union Telegraph Co. v. Andrews, 216 U.S. 165 (1910) (Arkansas license fee for foreign corporations).

"[The Three-Judge Act] was enacted to remedy a well-known evil, viz. the activities of sovereign states too frequently enjoined by a single judge too prone to sign on the dotted line upon the request of public utilities." Northern P. Ry. v. Board of R.R. Comm'rs., 34 F.2d 295, 297 (D. Mont. 1929). 
so often doomed at the will of a single federal judge."1 The tension was further increased because of the procedures which then prevailed in the federal courts for the issuing of injunctions. Temporary restraining orders were often issued $e x$ parte, and interlocutory injunctions could be issued on affidavits alone. ${ }^{12}$ There 'was no statutory limitation on a judge's discretion to continue a temporary restraining order or an interlocutory injunction, and often such orders were continued indefinitely. ${ }^{13}$ Federal-state relations were at a crisis.

To cure the situation, it was proposed in Congress that the federal courts be deprived of jurisdiction altogether over suits challenging state laws. ${ }^{14}$ The proposal which received the most serious debate, however, was the bill for a ThreeJudge Act, which was finally passed in $1910 .{ }^{15}$ The act provided-as it does now -for the enlarged trial court and for a direct appeal by either party to the Supreme Court. The only power explicitly left to the single judge was the power to issue a temporary restraining order upon a showing of irreparable damage. But the impending hearing before the three-judge court was to be given precedence over all other cases on the calendar.

It was not long before the needs which had given rise to the act began to disappear. Only two years after its enactment the Federal Equity Rules were revised, extending to all injunction cases much the same protective procedure

11 The congressional debates on the proposed Three-Judge Act reflected this feeling. See 42 CoNG. REC. 4846-59 (1908); 45 id. 7253-57 (1910). A typical statement of Senator Overman of North Carolina was this: "Whenever one judge stands up in a State and enjoins the Governor and the Attorney General, the people resent it, and public sentiment is stirred, as it was in my State, when there was almost a rebellion, whereas if three judges declare that a state statute is unconstitutional the people would rest easy under it. . . The whole purpose of the proposed statute is for peace and good order among the people of the States." 45 CONG. REC. at 7256. Of the Supreme Court's decision in Ex parte Young, Senator Bacon of Georgia stated: "[T]he decision trampled on the rights of the State of Minnesota, and I may add that if it trampled on the rights of the State of Minnesota, it necessarily trampled upon the rights of every other State.... If these subordinate courts can exercise such power, then, indeed, the States are but provinces and dependencies." $42 \mathrm{id}$. at 4853 . On Senator Bacon's motion, the dissenting opinion of Mr. Justice Harlan, which covers thirty-six pages of the United States Reports, was inserted in its entirety into the Congressional Record. 42 id. at 4853-58.

${ }^{12}$ See Hutcheson, supra note 1, at 801. Cf. Lindsley v. Natural Carbonic Gas Co., 162 Fed 954, 960 (C.C.S.D.N.Y. 1908).

${ }^{13}$ See the statement of Senator Crawford of South Dakota in 45 CoNG. REc. 7256 (1910). The judge's discretion as to continuing such preliminary orders was restrained only by general equitable principles. The controlling statutes were 17 Stat. 197 (1872), and Equity R. 55, 17 Pet. (Unofficial) lxx (1843). See Hutcheson, supra note 1, at 800-01.

1442 Cong. REc. 4847 (1908). A proposal also was submitted providing that the district courts be deprived only of the power to issue temporary restraining orders and interlocutory injunctions against the enforcement of state laws. Ibid.

${ }^{15}$ See 42 CoNG. REc. 4846-59 (1908); 45 id. 7253-57 (1910). The act originally applied only to the granting of interlocutory injunctions restraining the enforcement of statutes. However, in order to broaden the scope of the act, and in order to avoid the anomaly of having one judge review the order of three judges at the final hearing, the act was amended in 1913 to apply to administrative orders as well as to statutes, and in 1925 to apply to final injunctions as well as to interlocutory injunctions. See note 1 supra. 
which the Three-Judge Act had introduced for cases before the enlarged court. Under the new rules, for example, the continuance of a temporary restraining order for more than ten days was prohibited under any circumstances..$^{16}$ Even more important was a series of later federal statutes aimed at curtailing the power of federal courts to restrain state action. The two most important of these, the Johnson Act of $1934^{17}$ and the Tax Injunction Act of 1937,18 deprive the district courts of jurisdiction to enjoin the enforcement of state public utility rate orders and the collection of state taxes. The most important condition for the operation of the Johnson Act, and the only condition for the Tax Injunction Act is that "a plain, speedy and efficient remedy" be available in the state courts..$^{19}$ The district courts are thus deprived of jurisdiction in the two areas in which the need for the three-judge court was most strongly felt.

A change appeared also in the nature of the controversies arising under the Three-Judge Act. The once burning federal-state controversy soon subsided, and in an ever increasing number of cases the constitutional question had already been decided. The courts responded to this development by reinterpreting the act to allow more power to the single judge. The early decisions indicated that the single judge had been left without power even to determine whether or not a case fell under the act. So long as the complaint requested injunctive relief on the ground of unconstitutionality, the statutory court had to be summoned. ${ }^{20}$ But in Ex parte Poresky ${ }^{21}$ the Supreme Court, while recognizing that a single judge could never pass on the merits of a complaint which fell within the terms of the Three-Judge Act, held that he nevertheless had the power to dismiss such

${ }^{16}$ Equity R. 73, 198 Fed. xxxix (1912). This rule superseded Rule 55, supra note 13 . See Annotated Rules of Practice in the United States Courts 584-95. (Dewhurst ed. 1914).

1748 Stat. 775 (1934), now 28 U.S.C. \$1342.

${ }^{18} 50$ Stat. 738 (1937), now 28 U.S.C. $\$ 1341$.

${ }^{19}$ The Johnson Act of 1934 lists three other conditions for its operation: jurisdiction must be based solely on diversity of citizenship or repugnance to the Federal Constitution; the order under attack must not interfere with interstate commerce; and the order must have been made after reasonable notice and hearing.

${ }^{20}$ See Ex parte Metropolitan Water Co., 220 U.S. 539, 545 (1911): "the statute evidences the purpose of Congress that the application for the .... injunction should be heard before the enlarged court, whether the claim of unconstitutionality be or be not meritorious. ..." See also Ex parte Northern P.R.R., 280 U.S. 142 (1929); Stratton v. St. Louis S.W.R.R., 282 U.S. 10 (1930); Ex parle Madden Bros., 283 U.S. 794 (1931) (mem.); Bowen, supra note 1, at 23-24, 42. In Ex parte Madden Bros., supra, the single judge had dismissed the complaint for want of jurisdiction over the subject matter, and the Supreme Court granted mandamus to compel formation of a three-judge court to rehear the case. The Supreme Court did not make it clear, however, whether the writ was granted because the single judge was without power to dismiss by himself for want of jurisdiction or because his decision on the question of jurisdiction was wrong. The case below is reported, stub. nom. Madden Bros. v. Railroad \& Warehouse Comm'n., 43 F.2d 236 (D. Minn. 1930).

${ }^{21} 290$ U.S. 30 (1933). This was a suit attacking the Massachusetts compulsory auto insurance law. The district judge had dismissed the complaint on the ground that there was no "substantial federal question," since the Supreme Court had previously upheld that law. 
a case for want of jurisdiction. This distinction proved unworkable in practice.22 Still further powers had to be given the district judge to dispose of the many cases which clearly did not merit the imposition on the judiciary of a three-judge court. Another step was taken in California W ater Service Co. v. City of Redding,,23 where the Supreme Court stated that the single judge has not only the power but has also a duty to deny the statutory court whenever he is convinced that the constitutional question before him is not a "substantial" one. ${ }^{24}$ Such a finding usually amounts to an adjudication on the merits. ${ }^{25}$ Several writers have protested against this extension of the powers of the single judge, ${ }^{26}$ but the courts have unanimously upheld it. ${ }^{27}$ Indeed, the courts could not much further reduce the scope of the three-judge requirement without a change in the words of the act itself.

Another important factor reflecting on the present utility of the three-judge requirement is the judicially developed practice of the federal courts to abstain from exercising their jurisdiction when the constitutionality of a state law is at issue. Abstention is said to be appropriate where it "would serve one of two important countervailing interests: either the avoidance of a premature and perhaps unnecessary decision of a serious federal constitutional question or the avoidance of the hazard of unsettling some delicate balance in the area of federal-state relationships." 28 This doctrine often governs the outcome of cases

22 The facts of $E x$ parte Poresky provide a good example of why this was so. In any case where jurisdiction is claimed on the basis of a "federal question," see 28 U.S.C. $\$ 1331$ (1958), and where the only "federal question" alleged is that which is presented by the plaintiff's claim that the statute under attack is unconstitutional, a dismissal for want of jurisdiction really amounts to a decision on the merits of the case.

23304 U.S. 252 (1938).

24 "It is . . . the duty of a district judge . . . to scrutinize the bill of complaint, to ascertain whether a substantial federal constitutional question is presented, as otherwise the provision for the convening of a three judge court is not applicable. .. . The lack of substantiality in a federal question may appear either because it is obviously without merit, or because its unsoundness so clearly results from the previous decisions of this court as to foreclose the subject." 304 U.S. at 254-55. For a list of cases in which single district judges have refused to convene a three-judge court on the authority of the Redding case, see notes 63 and 64 , infra.

${ }^{25}$ See note 22 supra.

${ }^{26}$ Berueffy, supra note 1; Note, 47 GEo. L. J. 168, 172 (1959). See Eastern States Petroleum Co. v. Rogers, 265 F.2d 593, 595-97 (D.C. Cir. 1959); Note, 62 Harv. L. REv. 1398 (1949). It was intended by some of those who supported the passage of the 1942 procedural amendment to the Three-Judge Acts, now 28 U.S.C. $\$ 2284$, that the new section would operate to deprive the single judge of all power to decide whether three judges are required whenever the complaint requests an injunction against a statute on the ground of unconstitutionality. See H.R. REP. No. 1677, 77th Cong., 2d Sess. 5 (1942). The relevant portions of $\$ 2284$ read: "In any action ... required . . . to be heard by three judges . . . (5) . . . A single judge shall not ... hear and determine any application ... . or dismiss the action, or enter a summary or final judgment. ..." Such an interpretation would seem, however, to be inconsistent with the language of the section. The opening words of the section indicate that the entire section applies only to actions in which it has already been determined that three judges are required.

${ }^{27}$ See the cases cited in notes 63 and 64 infra.

${ }_{28}$ Martin v. Creasy, 360 U.S. 219, 225 (1959) (concurring opinion), quoting Louisiana Power \& Light Co. v. Thibodaux, 360 U.S. 25, 32 (1958) (dissenting opinion). See Railroad Comm'n. 
before three-judge courts. During the Supreme Court's last term, two important three-judge injunctions were reversed on the ground that the district courts should have withheld exercise of their jurisdiction..$^{29}$ The most frequently advanced rationale for abstention has been the first of those mentioned aboveavoidance of an unnecessary constitutional decision. Thus, abstention is most commonly exercised in cases in which a constitutional claim is joined in the alternative with a claim depending only on a construction of the law under attack. ${ }^{30}$ But in several recent cases the courts have abstained where the sole ground of attack on a state law was its alleged unconstitutionality. ${ }^{31}$ The rationale for abstention in such a case can only be the "scrupulous regard for the rightful independence of state governments which should at all times actuate the federal courts." ${ }^{32}$ The use of the abstention technique is increasing and is coming to replace the three-judge procedure as a protective device in the sensitive area of federal-state relations.

The second Three-Judge Act extended the procedure to suits seeking injunctions against allegedly unconstitutional acts of Congress. ${ }^{33}$ This act was not passed until 1937, twenty-seven years after the "state" Three-Judge Act had gone into effect. There is no indication that any need was felt for such an act before that time. It was designed to meet a specific problem-this time the struggle during the depression between the New Deal Congress and the more conservative judiciary. Most of the New Deal's key programs had been declared

of Texas v. Pullman Co., 312 U.S. 496 (1941); Chicago v. Fieldcrest Dairies, 316 U.S. 168 (1942); Burford v. Sun Oil Co., 319 U.S. 315 (1943); Spector Motor Service, Inc. v. McLaughlin, 323 U.S. 101 (1944); Stainback v. Mo Hock Ke Lok Po, 336 U.S. 368 (1949); Shipman v. DuPre, 339 U.S. 321 (1950); Alabama Public Service Comm'n. v. Southern Ry., 341 U.S. 341 (1951); City of Meridian v. Southern Bell Tel. Co., 358 U.S. 639 (1959); Harrison v. NAACP, 360 U.S. 167 (1959). See generally Kurland, Toward a Co-operative Judicial Federalism, 24 F.R.D. 481 (1960); Wright, The Abstention Doctrine Reconsidered, 37 TEXAS L. REV. 815 (1959); Note, 73 Harv. L. Rev. 1358 (1960); Note, 59 Colur. L. REv. 749 (1959); Note, 108 U. Pa. L. REv. 226 (1959).

An analogous doctrine was set forth by the Supreme Court in Prentis v. Atlantic Coast Line Co., 211 U.S. 210 (1908). There the Court held that when the state court procedure for review of an administrative order is "legislative, not judicial in kind," the federal courts should refuse to intervene until those procedures have been exhausted. A "legislative" review procedure was said to be one where the reviewing court has the power to substitute a new order of its own for that of the administrative agency. Id. at 224-25. Very few state courts have such power, however, and for that reason the Prentis doctrine has had only minor effect. See Note, 50 Harv. L. REv. 813,815 n.9 (1937).

${ }^{29}$ Martin v. Creasy, supra note 28 ; Harrison v. NAACP, supra note 28 . See also Louisiana Power \& Light Co. v. Thibodaux, supra note 28; Allegheny County v. Frank Mashuda Co., 360 U.S. 185 (1959); NAACP v. Bennett, 360 U.S. 471 (1959).

${ }^{30}$ E.g., Railroad Comm'n. v. Pullman Co., supra note 28; Harrison v. NAACP, supra note 28.

${ }^{31}$ E.g., Alabama Public Service Comm'n. v. Southern Ry., supra note 28; Atlantic Coast Line Co. v. City of St. Petersburg, 242 F.2d 613 (5th Cir. 1957).

32 Alabama Public Service Comm'n. v. Southern Ry., supra note 28, at 349.

${ }^{33}$ See note 1 supra. 
unconstitutional by single district judges. ${ }^{34}$ The friction between Congress and the courts grew intense, and strong pressures developed in Congress for control over the judiciary. ${ }^{35}$ One early proposal was that the government simply be allowed a direct appeal to the Supreme Court from injunctions restraining the enforcement of a "federal law." 36 The proponent of this bill, Senator Black (now Mr. Justice Black), predicted that the attorney general would exercise the right of direct appeal only in cases of "vast public moment." 37 Other proposals far more radical were made, ${ }^{38}$ however, and the debate in Congress continued for two years.

The final result of the debate was the Judiciary Act of $1937 .^{39}$ This act contained three important sections. The first section provided that the government may intervene in suits in which the constitutionality of an act of Congress is "called into question." The second section somewhat resembled Senator Black's earlier bill. It provided a direct appeal to the Supreme Court for any party to a suit in which an act of Congress is declared unconstitutional, and to which the

${ }^{34}$ See Injunctions in Cases Involving Acts of Congress, SEN. Docs. Nos. 25-33, 37-39, 41-44, 75th Cong., 1st Sess. (1937). Some of the more well known acts thus suspended were the Agricultural Adjustment Act, the National Recovery Act of 1933, the Emergency Relief Appropriations Act of 1935, the Public Utilities Holding Company Act of 1935, and the Tennessee Valley Authority Act. It was estimated by the Chairman of the TVA that the injunctions restraining the operation of the TVA cost the Authority and the consumers a total of $\$ 3,802,000$. SEN. Doc. No. 44, supra, at 5-9. See also Frankfurter and Fisher, supra note 1, at 616 n.69, and $618 \mathrm{n} .71$.

${ }^{35}$ For an indication of the feelings aroused in Congress by the injunctions granted against the TVA, see 81 CoNG. REC. 235-36, 2142-43 (1937). Compare the extreme statements of the district judges in Hart Coal Corp. v. Sparks, 7 F. Supp. 16, 28 (W. D. Ky. 1934); Duke Power Co. v. Greenswood County, 10 F. Supp. 854, 855-56 (W.D.S.C. 1935).

${ }^{36}$ S. 2176, 74th Cong., 1st Sess. See 81 CoNg. REc. 259-61 (1937).

${ }^{37}$ Hearings before the Committee on the Judiciary on S. 2176, 74th Cong., 1st Sess. 20 (1935). Of the cases which he had in mind Senator Black said: "I see no reason why we should not say to the Supreme Court, 'We will send the record up to you. ... It is not for you to determine whether you will take the case or not. Those who are charged primarily with enforcing the law in this country are bound to be in closer contact with the necessity for a speedy decision than you are in your court room, and they have determined that this is a case of such great national moment and importance that it must be decided at once." Ibid. Mr. Chief Justice Hughes and Justices Brandeis and Van Devanter appeared at the hearing and testified in opposition to Senator Black's bill. Id. passim.

i. ${ }^{38}$ E.g., S. 1174, 75th Cong., 1st Sess., 81 CoNg. REc. 482 (1937) (depriving the district and circuit courts of jurisdiction to issue injunctions against acts of Congress until such acts have been finally declared invalid by the Supreme Court); H.R. 4279, 75th Cong., 1st Sess., 81 Covg. REc. 820-21 (1937) (prohibiting all federal courts from passing upon the constitutionality of Acts of Congress); S. 1098, 75th Cong., 1st Sess., 81 Cong. REc. 411 (1937) (prescribing the number of Justices of the Supreme Court who must concur in holding an act of Congress unconstitutional). See also H.R. 50; H.R. 2265; and H.R. 3895, all 75th Cong., 1st Sess. (1937).

The most spectacular plan was President Roosevelt's proposal to "pack" the Supreme Court, S. 1392, 75th Cong., 1st Sess. (1937). That bill was adversely reported out by the Committee on the Judiciary, SEN. Rer. No. 711, 75th Cong., 1st Sess. (1937), and failed to pass in the Senate. See 81 CoNG. Rec. 7375-81 (1937).

${ }^{39} 50$ Stat. 732 (1937), as amended, 28 U.S.C. $\$ \$ 1252,2282,2403$ (1958). The bill before passage was H.R. 2260, 75th Cong. 1st Sess. (1937). 
United States is a party. Both of these sections remain in force. ${ }^{40}$ The third section of the Act of 1937 was the three-judge provision; it simply extended the "state" three-judge procedure, with its right of direct appeal, to cover suits seeking injunctions against acts of Congress. This section appears to have been added almost as an afterthought. Sections 1 and 2 of the act were extensively debated in Congress, ${ }^{41}$ but the three-judge section was not added to the bill until just before passage, and was never debated on the floor. ${ }^{42}$ The cases covered by the three-judge section and by section 2 of the act largely overlap. Sections 1 and 2 alone would seem to have effectively met the legislative crisis, providing as they do for intervention and for direct appeal from judgments which in fact declare acts of Congress unconstitutional. Indeed, it is diffcult to see how the three-judge provision contributed at all to the purposes for which the Judiciary Act of 1937 was designed.

But the needs which had given rise to the Judiciary Act disappeared almost with its passage. By 1937 the constitutionality of most of the New Deal program had been settled. Only a year after the Judiciary Act was passed the Supreme Court held that a three-judge court was not needed to pass upon a complaint seeking to enjoin enforcement of the National Recovery Act, since that act no longer raised a "substantial constitutional question." 43

\section{II}

This history suggests that the three-judge court has become an anachronism. The needs for which it was designed have largely disappeared, and its remaining functions have been taken over by other procedures. This alone, however, is not a convincing argument for abolition of the three-judge system; the system might still be justifiable as an extra-if not strictly "necessary"-safeguard against attack on future legislative programs. It is necessary now to look at the results which the three-judge procedure produces in operation. It will be seen that the procedure has proven to be an intolerable burden on the courts and a dangerous source of procedural pitfalls for litigants.

The most evident effect of the three-judge requirement on the courts is the disruption which it causes at the trial level, where a second district judge and a judge of the court of appeals must leave their own benches. Very serious inconvenience can result in a court which has a crowded docket or which is in an area

${ }^{10}$ Section 1 of the act, with minor amendments, is now 28 U.S.C. $\$ 2403$ (1958); section 2 , with minor amendments, is now 28 U.S.C. $\$ 1252$ (1958). The latter provides: "Any party may appeal to the Supreme Court from an interlocutory or final judgment, decree, or order of any court of the United States . . . holding an Act of Congress unconstitutional in any civil action, suit or proceeding to which the United States or any of its agencies . . is a party. . . " See ROBERTSON \& KIRKBAAr, op. cit. supra note 1, at 209-18.

${ }^{41}$ See 81 Cong. Rec. 3254-73, 8507-15, and 8701-02 (1937); SEN. REP. No. 963, 75th Cong., 1st Sess. (1937).

${ }^{42}$ See 81 Cong. Rec. 8702 (1937); Sen. ReP. No. 963, supra note 41, at 1, 4; H. R. REP. No. 1490, 75th Cong., 1st Sess. (1937).

${ }^{43}$ California Water Service Co. v. City of Redding, 304 U.S. 252 (1938). 
where federal judges are few and far between. ${ }^{44}$ It is not uncommon for a judge to make a trip of several hundred miles to complete a three-judge court. A dramatic example of this is provided by a recent case in Guam, ${ }^{45}$ in which a plaintiff had requested a three-judge court to pass on the constitutionality of a federal income-tax law. In denying the plaintiff's request, the single district judge implied in his opinion that it would be ludicrous to require two extra judges to travel thousands of miles simply to decide one case. The three-judge requirement suggests that the sitting judge does not have the ability or the judgment to decide such a case. ${ }^{46}$

A far more serious objection to the three-judge procedure lies in its imposition on the Supreme Court. The Three-Judge Acts carve out a large class of cases over which the Court is not permitted to exercise its traditional right of selective jurisdiction. ${ }^{47}$ The history of the acts suggests that the granting of direct appeal was of doubtful wisdom even when the acts were passed. Now that the controversies which they were designed to meet are a thing of the past, it is difficult to find any justification at all for Supreme Court review as of right. A look at the subject matter of the cases now coming to the Supreme Court from three-judge courts bears this out. There are few, if any, cases of "vast public moment"; nor is any nationwide legislative policy being frustrated in the district courts. ${ }^{48}$

${ }^{44}$ This argument was forcefully advanced by the opponents of the original Three-Judge Act in 1908. 42 CoNg. REc. 4851 (1908).

${ }^{45}$ Holbrook v. Taitano, 125 F. Supp. 14 (D. C. Guam 1954).

${ }^{46}$ It has been held that the "state" Three-Judge Act, 28 U.S.C. $\$ 2281$ (1958), does not apply in territories of the United States. Stainback v. Mo Hock Ke Lok Po, 336 U.S. 368 (1949).

${ }^{47}$ The history of this right and its importance to the efficient functioning of the Court are explored at some length in Frankfurter \& LaNDIS, THE BUSINESS OF THE SUPREME CoURT (1928), particularly at pp. 255-98. See also Justice Frankfurter's dissenting opinion in Ex parte Peru, 318 U.S. 578, 590 (1943); Hart, The Time Chart of the Justices, 73 Harv. L. Rev. 84 (1959).

${ }^{48}$ Beside Florida Lime and Avocado Growers v. Jacobsen, discussed in the text supra at notes 3-6, see Hershey Mfg. Co. v. Adamowski, 360 U.S. 717 (1959) (suit by manufacturer of slot machines attacking a state statu te which prohibits slot machines near army posts); NAACP v. Bennett, 360 U.S. 471 (1959) (state statute "affecting the National Association for the Advancement of Colored People"); Harrison v. NAACP, 360 U.S. 167 (1959) (state registration and barratry statutes); Martin v. Creasy, 360 U.S. 219 (1959) (state statute which authorizes construction of a limited access highway without providing in terms for compensation of adjoining property owners who have no direct access); Bibb v. Navaho Freight Lines, Inc., 359 U.S. 520 (1959) (state statute requiring trucks engaged in interstate commerce to be equipped with contour mudguards); State Athletic Comm'n. v. Dorsey, 359 U.S. 533 (1959) (state statute prohibiting prizefights between Negroes and whites); New Jersey v. United States, 359 U.S. 27 (1958) (act of Congress authorizing the Interstate Commerce Commission to permit abandonment of railroad service without having made a formal investigation); Federal Housing Administration v. The Darlington, Inc., 358 U.S. 84 (1958) (suit to restrain enforcement of a provision of the National Housing Act which prohibits rentals to transients, insofar as the provision applies to landlords who obtained FHA insurance prior to passage of the Act); Evers v. Dwyer, 358 U.S. 202 (1958) (state statute requiring Negroes to sit in rear of busses); Shuttlesworth v. Birmingham Board of Education, 358 U.S. 101 (1958) (state statute 
Perbaps the most far-reaching three-judge decisions of the past decade have been those involving school segregation. But even in those cases the three-judge procedure has not been very effective in expediting decision. The courts have been in disagreement as to whether the segregation issue raises a sufficiently "substantial and unsettled" constitutional question to bring it within the ThreeJudge Acts. Consequently, only some segregation cases have been decided by three-judge courts and appealed directly to the Supreme Court, while many of their companion cases have been decided by single judges and appealed through the courts of appeals. ${ }^{49}$

establishing criteria for placement of school children); Strong v. United States, 356 U.S. 226 (1958); Public Utilities Comm'n. of California v. United States, 355 U.S. 534 (1958); Corsa Fish Products Co. v. Tawes, 355 U.S. 37 (1957); Bryan v. Austin, 354 U.S. 933 (1957); Starr v. Nashville Housing Authority, 354 U.S. 916 (1957); Gulf Oil Corp. v. Corporation Comm'n. of Oklahoma, 354 U.S. 916 (1957); Morey v. Doud, 354 U.S. 457 (1957); Aero Design and Engineering Co. v. Oklahoma Employment Security Comm'n., 353 U.S. 943 (1957); Schenley Distillers v. Bingler, 353 U.S. 933 (1957); Government and Civic Employees, CIO v. Windsor, 353 U.S. 364 (1957); Gayle v. Browder, 352 U.S. 903 (1956); Baumann v. Smrha, 352 U.S. 863 (1956); Board of Trustees of the University of North Carolina v. Frasier, 350 U.S. 979 (1956); Nukk v. Shaughnessy, 350 U.S. 869 (1955); Doud v. Hodge, 350 U.S. 485 (1955); Combs v. Illinois State Highway Comm'n., 349 U.S. 942 (1955); Brown v. Board of Education, 347 U.S. 483 (1954); West Virginia Motor Truck Ass'n v. Public Service Comm'n. of West Virginia, 348 U.S. 881 (1954); Webb v. State University of New York, 348 U.S. 867 (1954); Williamson v. Lee Optical Co., 348 U.S. 483 (1955); Berman v. Parker, 348 U.S. 26 (1954).

This list contains all the cases which were found in the Court's last five full terms (19541958) in which the Court passed on appeals from three-judge district courts convened under $\$ \$ 2281$ and 2282 . There are thirty-one cases in all. Of the thirty-one, sixteen received only a memorandum opinion (i.e., no more than a statement of the disposition of the case), while fifteen received fuller treatment. This would seem to indicate that the Court did not feel most of the cases to be of "vast public moment." It is also interesting to note that in fifteen of the cases the law under attack was held constitutional, while in only six was it held unconstitutional. All of these six involved state laws. Ten of the cases were disposed of on other grounds, such as abstention, lack of a justiciable controversy, etc. Of the thirty-one cases, the decree of the district court was affirmed in eighteen, reversed in only six, vacated in five, and the appeal was dismissed in two. Twenty-three of the cases involved attacks on state laws, while only seven involved acts of Congress.

${ }^{49}$ The landmark decisions on school segregation were Brown v. Board of Education and its companion cases, 347 U.S. 483 (1954); and Bolling v. Sharpe, 347 U.S. 497 (1954)-five cases in all. Of the five, three were decided by three-judge courts and appealed directly to the Supreme Court, while one went through the state courts, reaching the Supreme Court via certiorari to the state Supreme Court, and one was decided by a single federal district judge and appealed to the court of appeals, ultimately reaching the Supreme Court by certiorari. The latter case, Bolling v. Sharpe, has a revealing history. The case arose in the District of Columbia. Two suits had been brought in the district court to enjoin enforcement of the District of Columbia's school segregation laws, $s u b$ nom. Bolling v. Sharpe and Cogdell v. Sharpe. In both cases the complaint was dismissed by a single district judge. Bolling v. Sharpe was then appealed to the court of appeals, and the Supreme Court granted certiorari before the court of appeals had rendered judgment. After the dismissal in Cogdell v. Sharpe, however, the plaintiffs pursued two courses of action simultaneously: first, they appealed the case on the merits to the court of appeals, and second, they applied in the Supreme Court for a writ of mandamus to compel the district judge to convene a three-judge court to rehear the case. The Supreme Court continued the mandamus proceeding to await the decision of the court of appeals on the appeal. Ex parte Cogdell, 342 U.S. 163 (1951). Nothing is subsequently reported as to either of the two Cogdell 
Alarm has recently been expressed at the insufficiency of time which the Supreme Court has for the important cases before it. It has been suggested that this insufficiency seriously hampers the Court in its work. ${ }^{50}$ The three-judge cases, as part of the Court's obligatory jurisdiction, exacerbate that problem. The Court has shown on several occasions that it is to be trusted to act swiftly in cases of real "public moment." Moreover, the Court may, in its discretion, directly review a case which has been appealed to the court of appeals by granting certiorari to the court of appeals before that court has rendered judgment. ${ }^{22}$ The Supreme Court would seem better qualified than Congress to judge which cases merit direct review.

Aside from placing a heavy burden on the courts, the three-judge procedure has been a source of procedural difficulties for litigants. The unusual problems which may arise when a "three-judge claim" is joined in a single complaint with a "non-three-judge claim" have been discussed above..$^{53}$ Far greater uncertainty surrounds the procedure for review of a refusal by the district court to convene a three-judge court. Very often a single district judge denies a request for a three-judge court. ${ }^{54}$ Sometimes, too, an already convened three-judge court finds that the case before it does not really require three judges and sends the case back to the original single judge. ${ }^{55}$ There is no statutory provision for review of such orders, ${ }^{56}$ and confusion prevails as to how such review may properly

cases, and the issue was ultimately decided in Bolling. The history of the three proceedings is recounted in Brief for Respondent in Opposition to Motion for Leave to File Petition for Mandamus, pp. 2-4, 30, 33, 36, Ex parte Cogdell. See also note 59 infra.

Since the Brown and Bolling decisions there has continued to be considerable difference in the district courts as to whether a suit attacking racial segregation in the public schools requires a three-judge court. A small majority of the courts have held that three judges are not required, on the ground that Brown and Bolling have foreclosed the constitutional question. The Supreme Court has continued to avoid settling the question either way. Compare Covington v. Montgomery County School Board, 139 F. Supp. 161 (M.D.N.C. 1956) (three-judge court held that three judges were unnecessary and remitted the case to the single judge) with Frasier v. Board of Trustees, 134 F. Supp. 589 (M.D.N.C. 1955), aff'd per curiam, 350 U.S. 979 (1956) (three-judge court rendered a decree and the Supreme Court accepted a direct appeal), and Cooper v. Aaron, 358 U.S. 1 (1958). See Reference, The Three Judge Federal Court, supra note 1, at 831-32.

${ }^{50}$ Hart, The Time Chart of the Justices, 73 HARv. L. REv. 84 (1959).

${ }^{51}$ See, e.g., United Steelworkers of America v. United States, 361 U.S. 39 (1959) (steel strike injunction); Cooper v. Aaron, 358 U.S. 1 (1958) (school segregation). The Supreme Court expedited decision in both of these cases. In the latter case it had been earlier held by the court of appeals that a three-judge court was unnecessary because there was not a substantial ques. tion of constitutionality. Aaron v. Cooper, 261 F.2d 97 (8th Cir. 1958). See note 49 supra.

52 See Sur. Cr. R. 20; 28 U.S.C. § 2101 (e) (1958). Cf. Bolling v. Sharpe, 347 U.S. 497 (1954).

${ }^{53}$ Pp. 556-57 supra.

54 Almost all the cases cited in notes 57-66 infra are of this type.

${ }^{55}$ E.g., Ex parte Gray, 342 U.S. 517 (1952); Ex parte Public National Bank, 278 U.S. 101 (1928); Shinaberry v. United States, 142 F. Supp. 413 (W. D. Mich. 1956); Davis v. County School Board, 142 F. Supp. 616 (E. D. Va. 1956); Willis v. Walker, 136 F. Supp. 181 (W.D. Ky. 1955); Frasier v. Board of Trustees, 134 F. Supp. 589 (M.D. N.C. 1955).

${ }^{66}$ The provision for direct appeal to the Supreme Court from decrees of the three-judge court, supra note 2 , has been held inapplicable to orders denying the three-judge court. 
be obtained. A brief analysis of this problem will serve to point out one of the difficulties inherent in the operation of the three-judge system.

The Supreme Court has indicated in several cases that the exclusive remedy of a party who has been wrongly denied a three-judge court lies in a writ of mandamus from the Supreme Court. ${ }^{57}$ Despite this rule, some courts of appeals in recent years have reviewed the order denying a three-judge court on appeal from the final decree of the single judge. ${ }^{58}$ Litigants are now in a position where the only safe course may be to pursue both of these procedures simultaneously. ${ }^{59}$ An appeal to the court of appeals presents important strategic advantages, but there is real danger that some courts of appeals will dismiss an appeal because of the "rule" that mandamus from the Supreme Court is the exclusive remedy. ${ }^{60}$

Eastern States Petroleum Corp. v. Rogers, 361 U.S. 7 (1959); Safe Harbor Water Power Corp. v. United States, 313 U.S. 546 (1941); Gross v. Title Insurance \& Trust Co., 305 U.S. 575 (1938).

${ }^{57}$ Ex parle Metropolitan Water Co., 220 U.S. 539 (1911); Ex parte Northern P. R.R., 280 U.S. 142 (1929); Stratton v. St. L.S.W. Ry., 282 U.S. 10 (1930); Ex parte Buder, 271 U.S. 461 (1926); Ex parte Smith, 274 U.S. 723 (1927); Ex parle Williams, 277 U.S. 267 (1928); Ex parte Collins, 277 U.S. 565 (1928); Ex parte Public National Bank, 278 U.S. 101 (1928); Ex parle Atlantic Coast Line Co., 279 U.S. 822 (1929); Ex parte Hobbs, 280 U.S. 168 (1929); Ex parte Poresky, 290 U.S. 30 (1933); Ex parte Bransford, 310 U.S. 354 (1940); Ex parte Madden Bros., 283 U.S. 794 (1931); Ex parte Cogdell, 342 U.S. 163 (1951); Ex parte Gray, 342 U.S. 517 (1952).

68 Carrigan v. Sunland-Tujunga Telephone Co., 263 F.2d 568 (9th Cir. 1959); Aaron v. Cooper, 261 F.2d 97 (8th Cir. 1958); White v. Gates, 253 F.2d 868 (D.C. Cir. 1958); Jacobs v. Tawes, 250 F.2d 611 (4th Cir. 1957); Wicks v. Southern P. R.R., 231 F.2d 130 (9th Cir. 1956), cert. and molion for leave to file petition for mandamus denied, 351 U.S. 946 (1956); Haines v. Castle, 226 F.2d 591 (7th Cir. 1955), cert. denied, 350 U.S. 1014 (1956); Van Buskirk v. Wilkinson, 216 F.2d 735 (1954); Board of Supervisors v. Tureaud, 207 F.2d 807 (5th Cir. 1953), and 225 F.2d 434 (5th Cir. 1955); Otten v. Baltimore \& O. R.R., 205 F.2d 58 (2d Cir. 1953); Florida Power Corp. v. Pinellas Utility Board, 181 F.2d 547 (5th Cir. 1950); Harvey v. Early, 160 F.2d 836 (4th Cir. 1947); Schermerhorn v. Holloman, 74 F.2d 265 (10th Cir. 1934) ${ }^{\circ}$

A petition for mandamus and an appeal are usually available simultaneously, since the order denying the three-judge court is in most cases accompanied by a dismisal of the complaint. See note 68 infra.

${ }^{59}$ This was the course followed by the petitioners in Eastern States Petroleum Corp. v. Rogers, - F.2d - (D.C. Cir., May 12, 1960), and in Ex parte Cogdell, 342 U.S. 163 (1951) described in note 49 supra. The inconsistency of the arguments which a litigant is forced to make when he is driven to pursue both the mandamus and appeal remedies at once may be effectively used against him. Compare Brief for Petitioner, pp. 20-24, Ex parte Cogdell, with Brief for Respondent, pp. 3-4, ibid.

The plain tiff in Wicks v. Southern P.R.R., 231 F.2d 130 (9th Cir. 1956), af ter having lost his appeal to the court of appeals on both the merits and the question of three-judge jurisdiction, found it necessary to petition the Supreme Court for certiorari and for leave to file a petition for mandamus in the alternative, having just "uncovered" the line of authorities which indicated that mandamus was his exclusive remedy when three-judge jurisdiction is at issue. Brief for Petitioner, p. 5, Wicks v. Brotherhood of Maintenance and Way Employees, 351 U.S. 946 (1956). The Supreme Court denied both in an uninformative memorandum opinion. Ibid.

${ }^{60}$ See Waddell v. Chicago Land Clearance Comm'n., 206 F.2d 748, 750 (7th Cir. 1953) (court of appeals held that three judges were not required below, but stated that if they had been the court of appeals would be without power to order a new trial); Chicago D. \& G. B. Transit Co. v. Nims, 252 F.2d 317, 319 (6th Cir. 1958) (same); Riss \& Co. v. Hoch, 99 F.2d 533 (10th Cir. 1938) (appeal dismissed for want of jurisdiction since three judges were required be- 
And a litigant who pursues but one remedy may find that he has made an unfortunate choice and that the alternative is barred by limitations.

Despite the Supreme Court's mandamus rule, several reasons might be given why an appeal to the court of appeals is the more desirable procedure for reviewing the order denying the three-judge court. First, the Supreme Court should not be burdened with cases which can be adequately handled by the courts of appeals. The question of whether a particular case falls within one of the ThreeJudge Acts is seldom a difficult one. Indeed, the decisions of district judges on that question are very rarely reversed..$^{61}$ The reasons commonly given for refusing to convene the three-judge court give an indication of why this is so. The most frequent reason for denying the court is that the case does not present a "substantial constitutional question." might appear either because the plaintiff's claim is without merit on its face, ${ }^{63}$ or because his claim is foreclosed by previous decisions. ${ }^{64}$ Other common reasons for denying the three-judge court are that the district court is in any event without jurisdiction over the subject matter of the complaint, ${ }^{65}$ and that the law under attack is not of the type covered by the Three-Judge Acts. ${ }^{66}$ If the Su-

low); Smith v. Dudley, 89 F.2d 453 (8th Cir. 1937) (same). It should be noted, however, that a dismissal may have the effect of an order for new trial, if the court of appeals makes clear its opinion that three judges are required, and if the district judge is amenable to the suggestion. See McCormick v. Brown, 52 F.2d 934 (4th Cir. 1931) (appeal dismissed), and 58 F.2d 994 (S.D. W.Va. 1931) (three-judge trial).

61 The Supreme Court has granted mandamus to compel formation of a three-judge court in only five cases. Ex parte Metropolitan Water Co., 220 U.S. 539 (1911); Ex parte Atlantic Coast Line Co., 279 U.S. 822 (1929); Ex parte Northern P.R.R., 280 U.S. 142 (1929); Stratton v. St. X.S.W.R.R., 282 U.S. 10 (1930); Ex parte Madden Bros., 283 U.S. 794 (1931). See Board of Sup'rs. v. Tureaud, 207 F.2d 807 (5th Cir. 1953); McCormick v. Brown, 52 F.2d 994 (S.D. W.Va. 1931).

${ }^{62}$ See California Water Service Co. v. City of Redding, 304 U.S. 252 (1938), quoted in part in note 24 supra.

${ }^{63}$ E.g., Carrigan v. Sunland-Tujunga Telephone Co., 263 F.2d 568 (9th Cir. 1959); Van Buskirk v. Wilkinson, 216 F.2d 735 (1954); Harvey v. Early, 160 F.2d 836 (4th Cir. 1947); Carras v. Monaghan, 65 F. Supp. 658 (W.D. Pa. 1946); Patterson v. Hardin, 145 F. Supp. 299 (S.D. Ind. 1956).

${ }^{64}$ E.g., Ex parte Poresky, 290 U.S. 30 (1933); White v. Gates, 253 F.2d 868 (D.C. Cir. 1958); Wicks v. Southern P.R.R., 231 F. 2d 591 (7th Cir. 1955); Otten v. Baltimore \& O.R.R., 205 F. 2d 58 (2d Cir. 1953) Simonoff v. Murf, 164 F. Supp. 34 (S.D.N.Y. 1958); Covington v. Montgomery County School Board, 139 F. Supp. 161 (M.D.N.C. 1956); O'Rourke v. Waterfront Comm'n., 118 F. Supp. 236 (S.D.N.Y. 1954).

${ }^{65}$ E.g., Eastern States Petroleum Co. v. Rogers, 265 F.2d 593 (D.C. Cir. 1959); Jacobs v. Tawes, 250 F.2d 611 (4th Cir. 1957); Ashley-Cooper Sales Service Co. v. Brentwood Mfg. Co., 168 F. Supp. 742 (D. Md. 1958). See Priceman v. Dewey, 81 F. Supp. 557 (E.D. N.Y. 1949) (want of equity jurisdiction; same litigation was pending in state court); Haymes v. Landon, 115 F. Supp. 506 (S.D. Cal. 1953) (want of equity jurisdiction; administrative remedies were unexhausted).

${ }^{66}$ E.g., Ex parte Williams, 277 U.S. 267 (1928) (tax assessments held not within the contemplation of the Three-Judge Acts); Ex Parte Collins, 277 U.S. 565 (1928) (city ordinances not covered); Schermerhorn v. Holloman, 74 F.2d 265 (10th Cir. 1934) (tax assessment). See 
preme Court's mandamus rule were actually followed by all the courts of appeals, it would have the effect of crowding the Supreme Court docket with a great many insubstantial claims.

Review by appeal to the court of appeals is also preferable from a strategical standpoint. If the court of appeals should find that the three-judge court was not required below, it can go on to review the merits of the decree which was entered, disposing of the entire case at once. In a mandamus proceeding, on the other hand, the Court can consider only the question of whether the three-judge court was in fact required; in either event the parties must be sent back, for either a new trial or for an appeal on the merits to the court of appeals. The mandamus remedy does present an advantage in that it allows for interlocutory review of the order denying the three-judge court, whereas an appeal may not be taken until either a final decree or a decision on a motion for an interlocutory injunction has been entered. ${ }^{67}$ This, of course, can be a decisive consideration when a long trial is expected. But practically speaking, it has not proved important; in most cases the order denying a three-judge court is accompanied by a dismissal of the complaint..$^{68}$

Still another reason for preferring the remedy by appeal may be found in the federal courts' rule that an extraordinary writ is improper whenever an adequate remedy may be had by appeal. The mere fact that so many courts of appeals now satisfactorily dispose of appeals on the point of three-judge jurisdiction offers a strong argument against the propriety of the granting of mandamus by the Supreme Court. ${ }^{69}$

Phillips v. United States, 312 U.S. 246 (1941), in which the Supreme Court held that a threejudge court had been improperly convened to pass on the constitutionality of a state order to halt work on a dam project, since the three-judge procedure is intended only for suits threatening "an improvident statewide doom by a federal court of a state's legislative policy." $I d$. at 251. Compare cases cited in HART \& WECHSLeR, op. cit. supra note 1, at 850-51.

${ }^{67} 28$ U.S.C. \$ 1291 (1958).

${ }^{68}$ Only three of the sixteen petitions for mandamus to compel formation of a three-judge court which are listed in note 57 supra, were filed before the single judge had rendered either a decision on a motion for an interlocutory injunction or a final decree. The three are Ex parte Bransford, 310 U.S. 354 (1940); Ex parte Williams, 277 U.S. 822 (1929); Ex parte Public National Bank, 278 U.S. 101 (1928).

${ }^{69}$ See BankersLife and Cas.Co.v. Holland,346 U.S.379,382-83(1953), in which theSupreme Court, refusing a writ of mandamus,stated: "[The] decision against petitioner, even if erroneous ... is reviewable upon appeal after final judgment. If we applied the reasoning advanced by the petitioner, then every interlocutory order which is wrong might be reviewed under the All Writs Act. The office of a writ of mandamus would be enlarged to actually control the decision of the trial court rather than used in its traditional function of confining a court to its prescribed jurisdiction. ... The supplementary review power conferred on the courts by Congress in the All Writs Act is meant to be used only in the exceptional case where there is clear abuse of discretion or 'usurpation of judicial power. ..." "See also Ex parte Peru, 318 U.S. 128, 134 (1918); Ex parle United States, 287 U.S. 241 (1932); Ex parte Slater, 246 U.S. 128, 134 (1918). Cf. Sloss, Mandamus in the Supreme Court since the Judiciary Act of 1925, 46 HARv. L. Rev. 91 (1932). Sup. Cr. R. 30 provides: "The issuance by the Court of any writ authorized by 28 U.S.C. $\$ 1651$ (a) [The All Writs Act] is not a matter of right but of sound discretion sparingly exercised." 
But even if there were a single clear cut remedy for the party who has been wrongly deprived of three judges-whether the remedy be by mandamus or appeal一what are the consequences of pursuing that remedy? Speed, which is often of the essence where the enforcement of a law is sought to be restrained, would not be promoted. Indeed, the disposition of the case would probably be postponed if the new trial were ordered, to be followed in turn by a Supreme Court appeal. ${ }^{70}$ If more adequate deliberation is an objective of the three-judge system, the party denied a three-judge court would still not seem to be in a strong position to complain. By the time the reviewing court has ordered the new trial, the case will have been before two courts and several judges-the same as though an appeal had been taken on the merits alone to the court of appeals. One advantage which a litigant gains by securing a three-judge trial is that he automatically becomes entitled to an appeal to the Supreme Court. But this is often won at the cost of burdening the Supreme Court with an insubstantial claim.

It seems clear that in cases where the three-judge court has once been denied, the three-judge requirement is often no more than a device by which the party who lost his case before the single judge can secure a new hearing. If the case can be shown to fall within the Three-Judge Acts the new trial must be ordered, since the single judge's action is void for want of jurisdiction. Yet to order a new trial would seem to frustrate the purposes of the acts themselves. This dilemma is inherent in the operation of the three-judge system.

The possibility that the district judge may erroneously deny the three-judge court is not the only hazard to which the parties are exposed. Just as often the three-judge court is erroneously convened. ${ }^{71}$ The decree of an erroneously con-

\footnotetext{
${ }^{70}$ A ludicrous example of such delay is provided by Stratton v. St. Louis S.W.R.R.,282 U.S. 10 (1930). The final disposition of that case in the Supreme Court was postponed for almost two years because of the original jurisdictional "fault" in not summoning a three-judge court. The suit had been brought to restrain the enforcement of a franchise tax imposed by the State of Illinois on foreign corporations. Neither party requested a three-judge court at any point in the litigation. The district judge upheld the tax, 27 F.2d 1005 (S.D. Ill. 1928), and the circuit court reversed, 30 F.2d 322 (7th Cir. 1929). On certiorari, the Supreme Court found the jurisdictional fault on its own motion, and held that since the case fell under the Three-Judge Act, both courts had acted without jurisdiction. A subsequently formed three-judge court found the tax unconstitutional. The Supreme Court on direct appeal then reversed that decree on the ground that the plaintiff had an adequate remedy at law through payment of the tax under protest and a later action in assumpsit for its recovery. 284 U.S. 530 (1932). Ultimately the case went to the Supreme Court of Illinois, which held the tax unconstitutional.353 Ill.273, 187 N.E. 498 (1933).
}

71 E.g., Phillips v. United States, 312 U.S. 246 (1941) (the order sought to be enjoined was not statewide in its effect; see note 66 su(pra); Rorick v. Board of Comm'rs., 307 U.S. 208 (1939) (same); Jameson \& Co. v. Morgenthau, 307 U.S. 171 (1939) (no substantial constitutional question was presented); International Ladies' Garment Workers' Union v. Donnelly, 304 U.S. 243 (1938) (the suit was between private parties); Oklahoma Gas \& Elec. Co. v. Oklahoma Packing Co., 292 U.S. 386 (1934) (same); Gully v. Interstate Natural Gas Co., 292 U.S. 16 (1934) (the suit attacked merely a tax assessment; see note 66 supra); Healy v. Ratta, 289 U.S. 701 (1933) (application for interlocutory injunction was not pressed; see note 15 supra); Smith v. Wilson, 273 U.S. 388 (1927) (same); Moore v. Fidelity \& Deposit Co., 272 U.S. 317 (1926) (same). 
vened three-judge court is not void for want of jurisdistion, ${ }^{72}$ as is the decree of a single judge when three are required. However, the Supreme Court will dismiss an appeal from such a court as soon as the defect is discovered. This necessitates the delay and expense of a second appeal, ${ }^{73}$ this time to the court of appeals. But even that may not be possible. By the time the Supreme Court has dismissed the first appeal, the time for appealing to the court of appeals will probably have expired. ${ }^{74}$ This can be remedied only by securing an order from the Supreme Court directing the district court to enter a new decree from which a timely appeal can be taken. While in most cases the Supreme Court has been willing to issue such an order, in some cases it has refused to do so, leaving the appellant remediless. ${ }^{75}$ The only safe course would seem to be to file two appeals, one to the Supreme Court and one to the court of appeals, whenever there is doubt as to whether or not a three-judge court has been properly convened.

It is submitted that retention of the three-judge procedure is unjustified. The needs for which it was designed are largely a thing of the past, and its remaining functions have been taken over by other procedures. Far from furnishing speedy justice in cases of "vast public moment," the three-judge procedure has proven in operation to be a heavy burden on the courts and a source of procedural pitfalls for litigants. The Three-Judge Acts survive as little more than an expression by Congress of a lack of confidence in the judiciary.

72 Healy v. Ratta, supra note 71.

${ }^{73}$ The delay can be considerable. In Healy v. Ratta, supra note 71, for example, two years were lost between the original three-judge decree granting an injunction and the final decision in the Supreme Court, which reversed the same decree and dissolved the injunction. In the meantime, af ter theSupreme Court had dismissed a direct appeal on the ground that the threejudge court had been unnecessarily convened, the court of appeals had taken the appeal on the merits, 67 F.2d 554 (1st Cir. 1933), and the case had reached the Supreme Court by certiorari.

${ }^{74}$ An appeal to the court of appeals must be taken within thirty days from the entry of judgment in the district court. FED. R. Crv. P. 73 (a).

${ }^{75}$ E.g., Smith v. Wilson, 273 U.S. 388 (1927); Moore v. Fidelity \& Deposit Co., 272 U.S. 317 (1926). In the Smith case the plaintiff then applied to the Supreme Court for mandamus to compel the circuit court of appeals to accept his appeal even though it was too late. The Supreme Court denied the writ. Ex parte Smith, 274 U.S. 723 (1927). The case is discussed in Sloss, supra note 69 , at 99.

\section{FEDERAL HABEAS CORPUS AND INVOLUNTARY CONFESSIONS}

When a defendant in a state criminal prosecution challenges the admission of his confession, alleging it was coerced, ${ }^{1}$ states following the orthodox proce-

1 The United States Supreme Court first used the due process clause of the fourteenth amendment to upset a state conviction based on an involuntary confession in Brown v. Miss'ssippi, 297 U.S. 278 (1936). That conviction rested solely upon a confession obtained through physical violence. In Malinski v. New York, 325 U.S. 401 (1945), the Court held that the admission into evidence of a coerced confession automatically voids a conviction under the due process clause, no matter how persuasive the remaining evidence of guilt. This rule of "automatic reversal" was coupled with a progressively broadened concept of what constitutes involuntariness. E.g., Haley v. Ohio, 332 U.S. 596 (1948) (tender age); Watts v. Indiana, 338 